\title{
Kinerja Guru Ditinjau dari Gaya Kepemimpinan Kepala Sekolah dan Motivasi Kerja
}

\author{
Wayan Satria Jaya ${ }^{1 凶}$ \\ Sekolah Tinggi Keguruan dan Ilmu Pendidikan PGRI Bandar Lampung, Indonesia(1) \\ DOI: $\underline{10.31004 / \text { obsesi.v6i3.1738 }}$
}

\begin{abstract}
Abstrak
Kinerja guru dalam melakukan tugas dan tanggung jawab akan memberikan dampak yang besar terhadap tercapainya tujuan sebuah lembaga pendidikan. Tujuan tersebut akan tercapai jika kinerja kerja tersebut dipengaruhi gaya kepemimpinan kepala sekolah. Penelitian ini bertujuan untuk mengetahui kinerja guru pendidikan anak usia dini ditinjau dari gaya kepemimpinan kepala sekolah dan motivasi kerja. Adapun sampel pada penelitian ini yakni 56 orang guru Pendidikan anak usia dini di kota bandar lampung. Penelitian ini dilakukan dengan metode kuantitatif dengan melihat pengaruh dari variabel yang diteliti. Teknik pengumpulan data yang digunakan adalah kuisioner, dan dokumentasi. Teknik analisis data yang digunakan pada penelitian ini adalah regresi linier berganda. Hasil penelitian menunjukan bahwa gaya kepemimpinan kepala sekolah dan motivasi kerja guru Pendidikan Anak Usia Dini (PAUD) secara bersama-sama berpengaruh positif dan signifikan terhadap kinerja guru. Semakin tepat gaya kepemimpinan yang diterapkan, maka kinerja para guru akan semakin baik. Kinerja guru dapat ditingkatkan ketika para guru mempunyai motivasi kerja yang lebih baik.
\end{abstract}

Kata Kunci: kinerja guru; gaya kepemimpinan; motivasi kerja guru

\begin{abstract}
The performance of teachers in carrying out their duties and responsibilities will have a major impact on the achievement of the goals of an educational institution. This goal will be achieved if the work performance is influenced by the principal's leadership style. This study aims to determine the performance of early childhood education teachers in terms of the principal's leadership style and work motivation. The sample in this study was 56 early childhood education teachers in the city of Bandar Lampung. This research was conducted with quantitative methods by looking at the influence of the variables studied. Data collection techniques used are questionnaires and documentation. The data analysis technique used in this research is multiple linear regression. The results showed that the leadership style of the principal of early childhood education and the work motivation teachers together had a positive and significant effect on the performance teachers. The more precise the leadership style applied, the better the performance of the teachers. Teacher performance can be improved when teachers have better work motivation.
\end{abstract}

Keywords: teacher performance; Leadership style; Teacher's work motivation

Copyright (c) 2021 Wayan Satria Jaya.

$\triangle$ Corresponding author:

Email Address : wayansatriajaya@gmail.com (Lampung, Indonesia)

Received 27 March tahun, Accepted 22 August 2021, Published 3 September 2021 


\section{PENDAHULUAN}

Keberhasilan pelaksanaan pendidikan di sekolah tidak terlepas dari motivasi kerja dan kinerja guru yang mengajar di lembaga pendidikan tersebut. Semakin baik motivasi kerja dan kinerja guru, maka akan semakin terbuka peluang untuk tercapainya tujuan pendidikan yang optimal di sekolah (Utami et al., 2019). Begitupun sebaliknya semakin rendah motivasi kerja dan kinerja guru, maka akan semakin sulit dalam mencapai tujuan pendidikan yang optimal, (Awaru \& Ernawati, 2015) . Kinerja yang dicapai oleh seseorang merupakan hasil apakah seseorang telah mencapai tuntunan yang diinginkan oleh organisasi atau belum baik dilihat dari sisi kualitas maupun kuantitas (Paizal et al., 2019). Mencapai kinerja yang dikehendaki, seorang guru harus memahami betul apa yang diinginkan oleh kepala sekolah. Guru juga harus memiliki kemauan dan keterampilan untuk menyelesaikan tugas yang diberikan oleh guru (Gusman, 2014).

Kinerja guru dalam melakukan tugas dan tanggung jawab akan memberikan dampak yang besar terhadap tercapainya tujuan sebuah lembaga pendidikan (Janah et al., 2019). Guru merupakan tenaga edukatif yang berperan menjalankan tugas dengan kompeten dan profesional. Tidak hanya melakukan pengajaran atau mentrasferkan ilmu pengetahuan tetapi juga dituntut untuk mampu memberikan bimbingan, keteladanan, pelatihan, pada peserta didik dan pengabdian pada masyarakat serta melakukan tugas-tugas administrasi lainnya. Mendidik artinya meneruskan dan mengembangkan ilmu pengetahuan. Sedangkan melatih adalah mengembangkan keterampilan pada siswa (Nurussalami, 2018).

Gaya kepemimpinan merupakan kemampuan (seni) pemimpin atau kepala sekolah untuk mempengaruhi orang lain berupa perilaku baik secara perorangan maupun kelompok dalam mengikuti kehendaknya baik secara langsung maupun tidak langsung. Dapat dipahami bahwa, kepemimpinan tersebut muncul bersamaan dalam peranannya sebagai kepala sekolah. Lebih lanjut dikatakan bahwa, keberhasilan sekolah mencapai tujuannya, sangat ditentukan oleh gaya kepemimpinan seorang pemimpin (Rosyadi, 2015; Rukmana, 2019). Gaya kepemimpinan berkaitan dengan cara yang digunakan oleh manajer dalam mengatur dan mempengaruhi guru untuk meningkatkan kerja mereka dalam rangka pencapaian tujuan sekolah. Pemimpin memiliki hubungan yang sangat erat dengan motivasi dan kinerja guru (Aguswara \& Rachmadtullah, 2017). Setiap pemimpin memiliki sifat, watak, dan karakter masing-masing yang dipengaruhi oleh factor sifat yang dibawanya dari lahir maupun pembentukan dari lingkungan tempat dimana pemimpin itu tumbuh dan berkembang (Bayu Hendro Priyono, Nurul Qomariah, 2018). Karakter yang berbeda-beda ini menimbulkan penerapan gaya kepemimpinan yang berbeda-beda yang dilaksanakan oleh masing-masing pemimpin. Gaya kepemimpinan merupakan norma perilaku yang digunakan oleh seseorang pada saat orang tersebut mencoba mempengaruhi perilaku orang lain seperti yang ia lihat (Agus Jamaludin, 2017; Sukri, 2018).

Gaya kepemimpinan seseorang kepala sekolah dalam memimpin sekolah memiliki peran yang penting bagi kinerja yang dihasilkan oleh guru (Nurmasyitah et al., 2015a). Demikian pentingnya peran kepemimpinan dalam usaha mencapai tujuan suatu organisasi, sehingga dapat ditanyakan bahwa sukses atau kegagalan yang dialami oleh suatu organisasi sebagian besar ditentukan oleh kualitas kepemimpinan yang dimiliki oleh orang-orang yang diserahi amanat sebagai pemimpin dalam organisasi tersebut (Ady \& Wijono, 2013; Nasution \& Ichsan, 2020).

Motivasi kerja adalah proses psikologis pada diri seseorang akibat adanya interaksi antara persepsi, sikap, kebutuhan, dan keputusan seorang dalam lingkungannya. Motivasi yang dimiliki seseorang berpotensi untuk mengarahkan mencapai hasil yang optimal dan berkemungkinan juga belum tentu bersedia mencapai hasil yang optimal, sehingga diperlukan adanya pendorong agar seorang mau bekerja sesuai dengan keinginan sebuah lembaga tersebut, (Paizal et al., 2019; et al., 2018). Melaksanakan semua tugas guru diperlukan adanya dorongan atau motivasi kerja baik dari diri sendiri, atasan atau kepala sekolah atau lingkungan sekitarnya (Nurussalami, 2018). 
Selanjutnya, kepemimpinan sebagai konsep manajemen merupakan kemampuan seseorang untuk mempengaruhi orang lain dalam mencapai tujuan dengan antusias (Depitra \& Soegoto, 2018; Satriadi, 2017). Lebih lanjut dikemukakan bahwa, kepemimpinan adalah cara seseorang memimpin mempengaruhi prilaku bawahannya agar mau bekerja sama dan bekerja secara produktif untuk mencapai tujuan (Septyan et al., 2017; Yanoto, 2018). Dapat dipahami bahwa, pemimpin yang baik haruslah mampu memotivasi pegawainya dalam bekerja. Lebih lanjut dikemukakan bahwa, disamping kepemimpinan, faktor motivasi juga dapat mempengaruhi kinerja pegawai (ardana, 2014; Novian.D., 2014; Suryani, 2018). Dapat dipahami bahwa, motivasi yang dimiliki seseorang adalah merupakan potensi, dimana seseorang belum tentu bersedia untuk mengerahkan segenap potensi yang dimilikinya untuk mencapai hasil yang optimal, sehingga masih diperlukan adanya pendorong agar seorang pegawai mau bekerja sesuai dengan keinginan organisasi (J.N., 2014; Widayati \& Rahardjo, 2017). Dapat dipahami bawa, faktor-faktor yang dapat digunakan untuk meningkatkan kinerja dalam sebuah organisasi diantaranya adalah kepemimpinan yang diberlakukan dalam organisasi tersebut dan motivasi kerja (Azizah, 2017; Nuraini \& Siswanta, 2002; Soetopo et al., 2019).

Berdasarkan hasil wawancara yang dilakukan peneliti dengan guru Pendidikan anak usia dini di kota Bandar Lampung, diketahui bahwa gaya kepemimpinan yang diterapkan kepala sekolah dan motivasi kerja yang diberikannya kepada guru belum mampu meningkatkan kinerja yang baik dalam organisasi. Hal ini senada dengan penelitian Nurmasyitah et al., (2015) dan Frelly, (2016) bahwa gaya kepemimpinan kepala sekolah menerapkan gaya militer, dimana guru diperintah dan ada kesenjangan jabatan bahwa kepala sekolah lebih tinggi dari pada guru sehingga kinerja kerja guru menjadi kurang optimal atau dikatakan lemah. Dikuatkan dengan pernyataan Mahyuddin \& Yanti, (2018) ada beberapa aspek dalam kinerja guru PAUD, namun pada aspek penilaian hasil pembelajaran atau pelaksaannya belum optimal. Sedangkan menurut Pratiwi et al., (2021) bahwa kinerja seorang guru yang optimal dipengaruhi oleh gaya kepemimpinan seorang kepala sekolah. Berdasarkan permasalahan tersebut, peneliti tertarik untuk melakukan penelitian yang berhubungan dengan kinerja guru Pendidikan anak usia dini ditinjau dari segi gaya kepemimpinan kepala sekolah dan motivasi kerja guru Pendidikan anak usia dini dikota bandar lampung.

Penelitian mengenai kepemimpinan telah dilakukan oleh beberapa peneliti. Penelitian yang telah dilakukan oleh Fuchrudi, (2017) tentang pengaruh gaya kepemimpinan terhadap kinerja karyawan menunjukan bahwa gaya kepemimpinan berpengaruh secara positif dan signnifikan terhadap kinerja karyawan. Selanjutnya, penelitian yang telah dilakukan oleh Tri Cicilia, (2020) Pengaruh Gaya Kepemimpinan Terhadap Kinerja Guru Di SDN Dengkek 01 Pati menunjukan bahwa gaya kepemimpinan transformasional, otokratis, dan demokratis. Sebaliknya, memiliki hubungan positif dengan kinerja. berikutnya, peneltian yang telah dilakukan oleh Steenbergen \& Tuinhof (2009) tentang hubungan gaya kepemimpinan demokratis dan motivasi kerja dengan kinerja guru menunjukan bahwa gaya kepemimpinan demokratis dan motivasi kerja berhubungan secara langsung terhadap kinerja. Adapun penelitian Andriana et al., (2018) menunjukkan bahwa kinerja seorang guru pendidikan anak usia dini yang mempunyai pengalaman lebih lama lebih baik dari guru yang baru memiliki pengalaman mengajar. Selain itu, guru yang banyak mengikuti pelatihan lebih baik dari guru yang belum mengikuti pelatihan.

Gaya kepemimpinan kepala sekolah yang tepat sangat diperlukan untuk mengembangkan lingkungan kerja yang kondusif dan meningkatkan kinerja guru sehingga diharapkan akan menghasilkan produktivitas kerja yang tinggi. Dapat dipahami bahwa, pentingnya kinerja guru merupakan salah satu kekuatan eksternal yang dapat digunakan oleh seorang guru untuk melaksanakan pengaruhnya dalam menjalankan tugasnya. Selanjutnya dapat dipahami bahwa peningkatan kerja harus diringi motivasi yang tinggi, bekerja tanpa motivasi tentu sangat membosankan, karena tidak adanya unsur pendorong. Motivasi 
merupakan pemberian atau penggerak yang menciptakan kegairahan kerja seseorang agar mau bekerja sama, terintegrasi dan segala daya upaya untuk mencapai kepuasan

Berdasarkan pemaparan penelitian di atas bahwa gaya kepemimpinan dan kinerja guru sudah banyak diteliti. Namun, perbedaan peneliti ini dengan sebelumnya adalah peneliti perlu melakukan kajian secara ilmiah mengenai kinerja guru pendidikan anak usia dini di Kota Bandar Lampung ditinjau dari gaya kepemimpinan kepala sekolah dan motivasi kerja guru Pendidikan anak usia dini. Adapun tujuan dari penelitian ini adalah untuk mengetahui kinerja kerja guru pendidikan anak usia dini ditinjau dari gaya kepemimpinan kepala sekolah dan motivasi.

\section{METODOLOGI}

Penelitian ini menggunakan data kuantitatif. Adapun bentuk kaitan antar variabel dalam penelitian ini adalah:

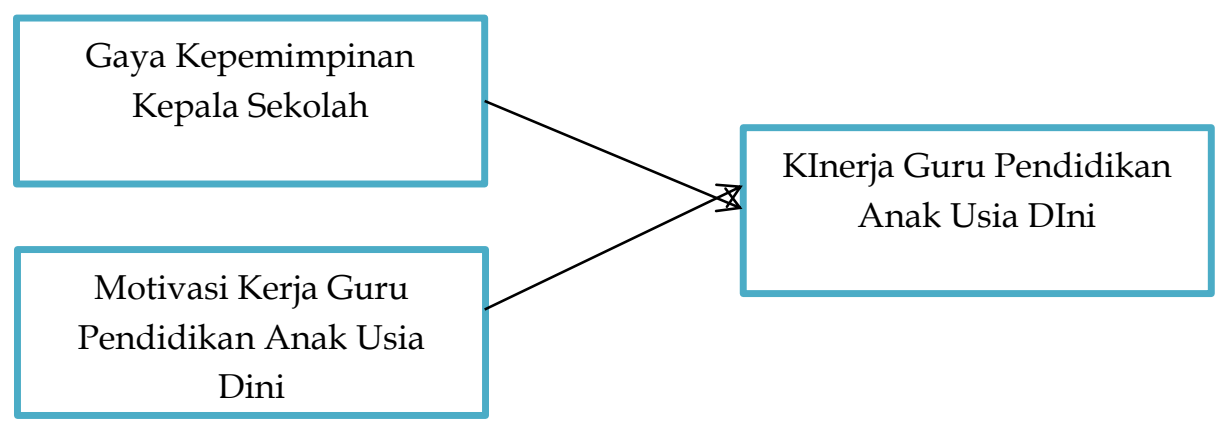

\section{Gambar 1. Bentuk Kaitan Antar Variable Penelitian}

Penelitian ini menggunakan sampel dengan probability sampling dengan pendekatan teknik random sampling. Pengambilan sampel anggota populasi dilakukan secara acak tanpa memperhatikan starta yang ada dalam populasi itu. Adapun jumlah sampel dalam penelitian ini adalah 56 orang guru Pendidikan anak usia dini di kota Bandar Lampung. Adapun teknik pengumpulan data pada penelitian ini adalah dengan menggunakan angket, dan dokumentasi. Angket yang digunakan adalah kuesioner yang telah teruji validitas dan reliabilitasnya.

Teknik analisis yang digunakan dalam penelitian ini adalah regresi linier berganda. Regresi linear berganda adalah regresi linear dimana variabel terikat dihubungkan dengan dua var iabel bebas dengan tujuan untuk mengetahui kinerja guru Pendidikan anak usia dini ditinjau dari gaya kepemimpinan kepala sekolah dan motivasi kerja guru Pendidikan anak usia dini.

\section{HASIL DAN PEMBAHASAN}

Setelah melakukan penelitian, peneliti menganalisis data yang telah didapatkan . berikut merupakan paparan hasil penelitian yang telah dianalisis:

Table 1. Hasil Pengujian Regresi Berganda

\begin{tabular}{llrrrrr}
\hline \multicolumn{1}{c}{ Model } & \multicolumn{2}{c}{$\begin{array}{c}\text { Unstandardized } \\
\text { coefficients }\end{array}$} & $\begin{array}{c}\text { Standardized } \\
\text { coefficients }\end{array}$ & T & Sig. \\
\cline { 2 - 6 } & \multicolumn{1}{c}{ B } & Std. error & Beta & & \\
\hline $1 \quad$ (constant) & 4.234 & 4.370 & & .971 & .336 \\
Gaya kepemimpinan & .472 & .127 & .431 & 3.723 & .000 \\
Motiasikerja & .359 & .132 & .314 & 2.712 & .009 \\
\hline
\end{tabular}


Berdasarkan Tabel 1 dapat dipahami bahwa, gaya kepemimpinan kepala sekolah dan motivasi kerja memiliki pengaruh terhadap kinerja guru Pendidikan anak usia dini. Terlihat bahwa $Y=4,243+0,472 X_{1}+0,359 X_{2}$ yang artinya nilai konstanta sebesar 4, 243 menyatakan bahwa jika gaya kepemimpinan dan motivasi kerja sebasar 0 , maka nilai kinerja guru Pendidikan anak usia dini sebesar 4,243. Selanjutnya, nilai koefeisien gaya kepemimpinan kepala sekolah sebesar 0,472 manyatakan bahwa setiap peningkatan satu satuan skor gaya kepemimpinan kepala sekolah akan meningkatkan skor kinerja guru Pendidikan anak usia dini sebesar 0,472 .

Nilai kofesien motivasi kerja guru Pendidikan anak usia dini sebesar 0,359 bernilai positif menyatakan bahwa setiap peningkatan satu satuan skor motivasi kerja guru Pendidikan anak usia dini akan meningkatkan skor kinerja sebesar 0,359 . Selanjutnya nilai regresi berganda didapatkan positif, dapat dipahami bahwa jika ada peningkatan gaya kepemimpinan kepala sekolah maka akan mengakibatkan peningkatan kinerja pegawai dan motivasi tetap. Berdasarkan hasil uji statistik mengenai kinerja guru Pendidikan anak usia dini ditinjau dari gaya kepemimpinan kepala sekolah dan motivasi kerja guru Pendidikan anak usia dini diperoleh nilai signifikansi sebesar $\leq 0,05$ dengan demikian dapat dipahami bahwa gaya kepemimpinan kepala sekolah Pendidikan anak usia dini dan motivasi kerja guru Pendidikan anak usia dini secara Bersama-sama berpengaruh positif dan signifikan terhadap kinerja guru Pendidikan anak usia dini di Kota Bandar Lampung.

Hasil analisis menunjukkan bahwa gaya kepemimpinan kepala sekolah dan motivasi kerja berpengaruh positif signifikan terhadap kinerja para guru Pendidikan anak usia dini di kota Bandar Lampung. Dapat dipahami bahwa gaya kepemimpinan yang tepat akan mampu membangkitkan gairah para guru yang selanjutnya para guru berkinerja lebih baik. Selanjutnya motivasi kerja guru yang meliputi guru dengan produktivitas yang tinggi, selalu bersemangat ketika bekerja, mempunyai inisiatif ketika kesulitan dalam bekerja, pekerjaan membutuhkan kreatifitas yang tinggi dan bertanggung jawab akan pekerjaan untuk mencapai target kerja, berpengaruh terhadap kinerja guru.

Berdasarkan pemaparan di atas, gaya kepemimpinan kepala sekolah serta motivasi kerja memiliki peran yang sangat penting di dalam meningkatkan kinerja seorang guru. Dapat dipahami bahwa di dalam dunia pendidikan, seorang guru merupakan ujung tombak pendidikan. Lebih lanjut, jika Guru bisa menyampaikan materi dengan baik, memiliki kompetensi yang mumpuni serta memiliki motivasi kerja yang tinggi, maka tujuan pendidikan yang telah disepakati secara bersama dapat tercapai.

Hasil penelitian sejalan dengan kepemimpinan transformasional membantu membangun sistem nilai bersama memberikan bawahan kesempatan untuk kembangkan keterampilan dan kemampuan mereka (Azis \& Suwatno, 2019; Dzikrillah Rizqi Amalia Bambang Swasto Heru Susilo Saragih, 2018). Gaya Kepemimpinan yang demokratis membantu meningkatkan kreativitas dan keterampilan pengambilan keputusan para bawahan. Dalam gaya kepemimpinan otokratis, bawahan harus bekerja atau mengikuti perintah diberikan oleh pemimpin dan ini menguntungkan organisasi sesuai survei. Gaya kepemimpinan karismatik dan gaya kepemimpinan birokratis memiliki hubungan negatif dengan kinerja sekolah (Hanafi et al., 2018; Rosaliawati et al., 2020).

Penelitian Octavia, (2016) menunjukkan hasil yang sama bahwa gaya kepemimpinan kepala sekolah dapat mempengaruhi kinerja guru. Gaya kepemimpinan yang digunakan kepala sekolah adalah kelompok, seperti: melibatkan guru dalam mengambil keputusan/rapat sekolah, pendelegasian, kegiatan sekolah, mengajak guru-guru untuk mengikuti pelatihan, memberi motivasi, dan memberikan apresiasi kepada guru yang mempunyai prestasi. Adapun faktor yang mempengaruhi gaya kepemimpinan tersebut adalah seorang kepala sekolah yang mempunyai jiwa disiplin, berorientasi pada tugas, guru yang mau berkembang, memberikan pengarahan, memberikan apresiasi, dan tidak membentuk sebuah grup khusus. 
Didukung oleh penelitian Nafiqoh, (2017) kepemimpinan seorang kepala sekolah dikategorikan baik jika kepala sekolah menunjukkan kepemimpinan partisipatif, bertanggung jawab, memberikan motivasi, memberikan pertimbangan. Dalam penelitian ini kepala sekolah memberikan dukungan yang baik dalam motivasi berprestasi yang meliputi faktor motivator dan higien. Dengan kata lain, kinerja guru dipengaruhi oleh kepemimpinan kepala sekolah dan motivasi berprestasi guru yang positif. Kepala sekolah yang memiliki tanggung jawab yang baik akan meningkatkan kualitas kinerja dan motivasi berprestasi yang baik. Berbeda pendapat dengan Nursyam, (2020) selain gaya kepemimpinan ada faktor lain yang dapat mengembangkan kinerja seorang guru, yaitu : 1) sarana dan prasarana yang memadai. Jika sarana dan prasarana memadai maka guru dapat mengembangkan kinerjanya. 2) kebijakan pemerintah dalam melaksanakan program dalam mengembangkan kompetensi guru, perkembangan teknologi untuk guru dan anak didik. Namun demikian Rosyati et al. (2020) mendapati keberhasilan kepemimpinan kepala sekolah tergantung pada integritas guru. Dengan demikian antara kepala sekolah dan guru bersinergi dalam mewujudkan visi dan misi sekolah.

Kinerja seorang guru pendidikan anak usia dini sangatlah penting untuk menjadi fasilitator pembelajaran anak usia dini. Pada hasil penelitian (Alfionita et al., 2020) kinerja kerja pada terhadap kualitas pendidikan anak usia dini mempunyai pengaruh positif yang signifikan dalam meningkatkan kualitas PAUD. Selain faktor kinerja guru dalam meningkatkan kualitas PAUD terdapat faktor lain salah satunya kepemimpinan kepala sekolah yang baik dan efektif. Selain gaya kepemimpinan mempengaruhi kinerja kerja guru PAUD Djafri, (2020), adapun hasil penelitian Pratiwi et al., (2021) menunjukkan bahwa terdapat beberapa faktor yang mempengaruhi kinerja seorang guru pendidikan anak usia dini yaitu faktor psikologis (motivasi guru) dan faktor organisasi (disiplin guru).

Berdasarkan pemaparan di atas, dapat dipahami bahwa implikasi dari penelitian ini yaitu memberikan sumbangan pemikiran dalam usaha meningkatkan kinerja melalui pemahaman kepemimpinan dan motivasi kerja. Penelitian ini juga telah mampu memperkuat beberapa penelitian terdahulu terkait dengan kepemimpinan, motivasi, dan kinerja. Selanjutnya, keterbatasan dari penilitian ini adalah hanya menganalisis kinerja guru Pendidikan anak usia dini yang ditinjau dari gaya kepemimpinan kepala sekolah dan motivasi kerja. Padahal secara teoritis terdapat beberapa variabel yang mempengaruhi kinerja para guru seperti antara lain pendidikan dan pelatihan, tingkat kesejahteraan, tempat tinggal para guru, kepuasan kerja, dan pengalaman kerja menjadi guru. Sehingga beberapa variabel lain yang telah disebutkan juga memiliki pengaruh terhadap kinerja guru Pendidikan anak usia dini sehingga perlu dilakukan penelitian lebih lanjut. Diharapkan kepada para peneliti lain yang akan datang untuk tidak hanya meneliti variabel-variabel yang sudah diteliti oleh peneliti terdahulu tetapi juga meneliti variabel-variabel yang lain sehingga menemukan faktor yang menjadi determinan kinerja para guru.

\section{SIMPULAN}

Kepala sekolah merupakan penentu arah atau pengendali keberhasilan PAUD agar tercapainya tujuan yang diinginkan. Untuk itu, kerjasama yang baik antara kepala sekolah sangatlah penting dalam meningkatkan kualitas dijenjang pendidikan anak usia dini. Hasil tersebut dapat dipahami bahwa semakin tepat gaya kepemimpinan yang diterapkan, maka kinerja para guru akan semakin baik. Kinerja guru dapat ditingkatkan ketika para guru mempunyai motivasi kerja yang lebih baik. Lebih lanjut, penelitian ini telah memberikan sumbangan pemikiran dalam usaha meningkatkan kinerja guru melalui pemahaman gaya kepemimpinan kepala sekolah dan motivasi kerja.

\section{UCAPAN TERIMAKASIH}

Peneliti mengucapkan terimakasih kepada pihak-pihak yang terlibat dalam peneltian ini, terkhusus guru PAUD di Kota Bandar Lampung. 


\section{DAFTAR PUSTAKA}

Ady, F., \& Wijono, D. (2013). Pengaruh Motivasi Kerja terhadap Kinerja Karyawan. Jurnal Maksipreneur: Manajemen, Koperasi, Dan Entrepreneurship, 2(2), 101. https:// doi.org/10.30588/jmp.v2i2.278

Agus Jamaludin. (2017). Pengaruh Gaya Kepemimpinan Terhadap Kinerja Karyawan Pada Pt.Kaho Indahcitra Garment Jakarta. Resources Policy, 7(1), 1-10. https://doi.org/10.30998/jabe.v3i3.1767

Aguswara, W. W., \& Rachmadtullah, R. (2017). Pengaruh Gaya Kepemimpinan Kepala Sekolah Dan Iklim Organisasi Dengan Kinerja Guru Pendidikan Anak Usia Dini. JPUD - Jurnal Pendidikan Usia Dini, 11(2), 369-385. https:// doi.org/10.21009/JPUD.112.14

Alfionita, I. L., Muhaimi, L., \& Fahruddin. (2020). Pengaruh Kinerja Guru terhadap Kualitas PAUD di Gugus 3 Kabupaten Gerung. JPAP: Jurnal Praktisi Administrasi Pendidikan, 4(1), 3-5.

Andriana, J., Sumarsih, \& D., D. (2018). Kinerja Guru PAUD Ditinjau Dari Kualifikasi Pendidik, Pengalaman Mengajar, Dan Pelatihan. Jurnal Ilmiah Potensia, 3(2), 18-23. https:/ / ejournal.unib.ac.id/index.php/potensia/article/download/2521/2683

Ardana. (2014). analisis pengaruh gaya kepemimpinan, motivasi kerja dan kompensasi terhadap kinerja guru. Jurnal Pendidikan Ilmu Sosial, 24(1), 67-77.

Awaru, O. T., \& Ernawati. (2015). Pengaruh Gaya Kepemimpinan Transaksional Dan Transformasional Terhadap Kinerja Guru SMA di Kabupaten Sinjai. Jurnal Ad'ministrare: Jurnal Pemikirian Ilmiah Dan Pendidikan Administrasi Perkantoran, 2(1).

Azis, A. Q., \& Suwatno, S. (2019). Pengaruh Gaya Kepemimpinan Kepala Sekolah Terhadap Kinerja Guru di SMK Negeri 11 Bandung. Jurnal Pendidikan Manajemen Perkantoran, 4(2), 246. https:// doi.org/10.17509/jpm.v4i2.18020

Azizah, J. (2017). Pengaruh Gaya Kepemimpinan dan Motivasi Terhadap Kinerja Guru. Jurnal Manajemen Kinerja, 3(1), 57-63.

Bayu Hendro Priyono, Nurul Qomariah, P. W. (2018). pengaruh gaya kepemimpinan, motivasi guru dan lingkungan kerja fisik terhadap kinerja guru SMAN 1 Tanggul Jember. 4(2), 144-160. https:// doi.org/10.32528/jmbi.v4i2.1758

Depitra, P. S., \& Soegoto, H. (2018). Pengaruh Gaya Kepemimpinan Terhadap Kinerja Karyawan. Majalah Ilmiah UNIKOM, 16(2), 185-188. https:// doi.org/10.34010/miu.v16i2.1361

Djafri, N. (2020). Pengaruh Gaya Kepemimpinan dan Budaya Kerja Kepala Sekolah di Pendidikan Anak Usia Dini. Jurnal Obsesi : Jurnal Pendidikan Anak Usia Dini, 4(2), 940. https://doi.org/10.31004/obsesi.v4i2.494

Dzikrillah Rizqi Amalia Bambang Swasto Heru SusiloSaragih, A. Y. (2018). Kinerja karyawan ( Studi pada karyawan tetap di Pabrik Gula Kebon Agung Malang ). 61(2), 210-219.

Frelly, D. M. (2016). Kinerja pendidikan anak usia dini (paud) di kecamatan parigi barat kabupaten parigi moutong. E Jurnal Katalogis, 4(1), 140-146.

Fuchrudi, H. (2017). Pengaruh Gaya Kepemimpinan terhadap Kinerja Keryawan. Repositori IAIN Raden Intan Lampung.

Gusman, H. E. (2014). Hubungan gaya kepemimpinan kepala sekolah dengan kinerja guru di smp n kecamatan palembayan kabupaten agam. Jurnal Bahana Manajemen Pendidikan, 2, 293-301. https://doi.org/10.24036/bmp.v2i1.3764

Hanafi, Sukma, A., Almy, Siregar, C., \& Tirtana, M. (2018). Pengaruh Gaya Kepemimpinan Dan Motivasi Kerja Terhadap Kinerja Pegawai. Jurnal Manajemen Industri Dan Logistik, 2(1), 47. https://doi.org/10.30988/jmil.v2i1.71

J.N., L. (2014). Pengaruh Kepemimpinan, Motivasi, Dan Kedisiplinan Kerja TerhadapKinerja Karyawan Pada PT. BTN Cabang Syariah Pekan Baru. Paper Knowledge . Toward a Media History of Documents. 
Janah, R., Akbar, Z., \& Yetti, E. (2019). Pengaruh Iklim Organisasi terhadap Kinerja Guru PAUD di Kota Depok. Jurnal Obsesi : Jurnal Pendidikan Anak Usia Dini, 4(1), 234. https://doi.org/10.31004/obsesi.v4i1.236

Mahyuddin, N., \& Yanti, S. (2018). Kinerja Mengajar Guru PAUD dan Latar Belakang Pendidikan. Early Childhood Education Journal of Indonesian, 1(2), 24-30.

Nafiqoh, H. (2017). Motivasi Berprestasi Terhadap Kinerja Guru Pendidikan Anak Usia Dini. Tunas Siliwangi, 3(1), 57-75. https:// doi.org/10.22460/ts.v3i1p57-75.318

Nasution, L., \& Ichsan, R. N. (2020). Gaya Kepemimpinan Kepala Sekolah Terhadap Kinerja Guru. Jurnal Penelitian Pendidikan Sosial Humaniora, 5(2), 78-86. https://jurnallp2m.umnaw.ac.id/index.php/JP2SH/article/view/473

Novian.D. (2014). Hubungan Gaya Kepemimpinan Dan Motivasi Kerja Dengan Kinerja. Jurnal Studia, 2(2), 109-120.

Nuraini, M. A., \& Siswanta, L. (2002). Pengaruh Gaya Kepemimpinan Dan Disiplin Kerja Terhadap Kinerja Karyawan Stikes Surya Global Yogyakarta. 435-448.

Nurmasyitah, AR, M., \& Usman, N. (2015a). Gaya Kepemimpinan Kepala Sekolah Dalam Meningkatkan Kinerja Guru Pada Sd Negeri Lambaro Angan. Administrasi Pendidikan, 3(2), 159-168.

Nurmasyitah, AR, M., \& Usman, N. (2015b). Meningkatkan Kinerja Guru Pada Sekolah. Administrasi Pendidikan, 3(2), 159-168.

Nursyam, N. (2020). Gaya Kepemimpinan Kepala Sekolah Dalam Mengembangkan Kinerja Pendidik. Kelola: Journal of Islamic Education Management, 5(1), 27-38. https:// doi.org/10.24256/kelola.v5i1.1413

Nurussalami. (2018). Gaya Kepemimpinan Kepala Sekolah Terhadap Motivasi Kinerja Guru Pada SD Negeri Siem Kecamatan Darussalam Aceh Besar. Bunayya: Jurnal Pendidikan Anak, IV(2), 1-12.

Octavia, L. S., \& Savira, S. I. (2017). Gaya Kepemimpinan Kepala Sekolah dalam Upaya Meningkatkan Kinerja Guru dan Tenaga Kependidikan. Jurnal Dinamika Manajemen Pendidikan, 1(1), 7. https://doi.org/10.26740/jdmp.v1n1.p7-14

Paizal, I., Siraj, A., \& Mania, S. (2019). Hubungan Gaya Kepemimpinan Kepala Madrasah dengan Kinerja Guru di Madrasah Aliyah Pondok Pesantren Al-Ikhlas Ujung Bone. Jurnal Pendidikan Agama Islam Al-Thariqah, 4(1), 21-37. https:/ / doi.org/10.25299/althariqah.2019.vol4(1).3003

Pratiwi, W. A., Prasetyo, I., \& Shabrina, M. N. (2021). Faktor-Faktor yang Berpengaruh terhadap Kinerja Guru Taman Kanak-Kanak. Jurnal Obsesi : Jurnal Pendidikan Anak Usia Dini, 5(2), 1741-1753. https:/ / doi.org/10.31004/obsesi.v5i2.970

Rosaliawati, B. N., Mustiningsih, M., \& Arifin, I. (2020). Hubungan Gaya Kepemimpinan Kepala Sekolah Dan Kinerja Guru. Jurnal Administrasi Dan Manajemen Pendidikan, 3(1), 61-71. https://doi.org/10.17977/um027v3i12020p61

Rosyadi, Y. I. (2015). Peran Kepala Sekolah Sebagai Manajer Dalam Meningkatkan Mutu Pendidikan Di Smp 1 Cilawu Garut. Jurnal Akuntabilitas Manajemen Pendidikan, 3(1), 124-133. https://doi.org/10.21831/amp.v3i1.6276

Rosyati, T., Saprudin, S., \& Alaydrus, A. S. (2020). Kinerja OCB pada guru PAUD ditinjau dari Educational leadership dan Integritas. Jurnal Obsesi : Jurnal Pendidikan Anak Usia Dini, 5(1), 201. https://doi.org/10.31004/obsesi.v5i1.513

Rukmana, A. (2019). Pengaruh Gaya Kepemimpinan Kepala Sekolah dan Motivasi Kerja Guru Terhadap Kinerja Guru. Coopetition: Jurnal Ilmiah Manajemen, 9(1), 81-98. https://doi.org/10.32670/coopetition.v9i1.54

Satriadi, D. (2017). Pengaruh Gaya Kepemimpinan Dan Motivasi Terhadap Produktivitas Kerja. Jurnal Benefita, 2(1), 33. https://doi.org/10.22216/jbe.v2i1.1271

Septyan, F. B., Musadieq, M. Al, \& Mukzam, M. D. (2017). Motivasi dan Kinerja ( Studi Pada Karyawan CV . Jade Indopratama Malang ). Jurnal Administrasi Bisnis (JAB), 53(1), 81- 
88.

http://administrasibisnis.studentjournal.ub.ac.id/index.php/jab/article/viewFile/2 $\underline{185 / 2583}$

Siagian, T. S., \& Khair, H. (2018). Pengaruh Gaya Kepemimpinan Dan Lingkungan Kerja Terhadap Kinerja Karyawan Dengan Kepuasan Kerja Sebagai Variabel Intervening. Maneggio: Jurnal Ilmiah Magister Manajemen, 1(1), 59-70. https:// doi.org/10.30596/maneggio.v1i1.2241

Soetopo, I., Kusmaningtyas, A., \& Andjarwati, T. (2019). Pengaruh Gaya Kepemimpinan Transformasional, Karakteristik Individu, Lingkungan Kerja Terhadap Motivasi Kerja Dan Kinerja Guru Smk Negeri 1 Tambelangan Sampang. Jmm17, 5(02). https:// doi.org/10.30996/jmm17.v5i02.1947

Steenbergen, F., \& Tuinhof, A. (2009). Hubungan Gaya Kepemimpinan Demokratis Dan Motivasi Kerja Dengan Kinerja Guru. Angewandte Chemie International Edition, 6(11), 951-952, 27-41.

Sukri, K. (2018). Hubungan Gaya Kepemimpinan Transformasional Dan Religiusitas Dengan Kinerja Karyawan. Psikoislamedia : Jurnal Psikologi, 2(2), 116-130. https://jurnal.arraniry.ac.id/index.php/Psikoislam/article/view/1891

Suryani, N. L. (2018). Pengaruh Gaya Kepemimpinan Dan Motivasi Terhadap Kinerja Karyawan Pada PT. Boga Lesatri Sentosa. Jurnal Ilmiah, Manajemen Sumber Daya Manusia, 2(1), 92-108. https://doi.org/10.32493/JJSDM.v2i1.1937

Tri Cicilia. (2020). Pengaruh Gaya Kepemimpinan Terhadap Kinerja Guru Di SDN Dengkek 01 Pati. Jurnal JIEMAR, 1(2), 1-8.

Utami, W. Y. D., Jamaris, \& Meilanie, S. M. (2019). Evaluasi Program Pengelolaan Lembaga PAUD di Kabupaten Serang. Jurnal Obsesi : Jurnal Pendidikan Anak Usia Dini, 4(1), 67. https://doi.org/10.31004/obsesi.v4i1.259

Widayati, C., \& Rahardjo, T. H. (2017). Pengaruh Kepemimpinan Transformasional, Motivasi Dan Kompensasi Terhadap Kinerja Karyawan. Jurnal Ekonomi, 22(3), 466-485. https:// doi.org/10.24912/je.v22i3.286

Yanoto, A. (2018). Pengaruh Gaya Kepemimpinan terhadap Kepuasan Kerja melalui Motivasi dan Kinerja Karyawan PT. Nutrifood Indonesia di Surabaya. Jurnal Agora, 6(1), 1-10. 